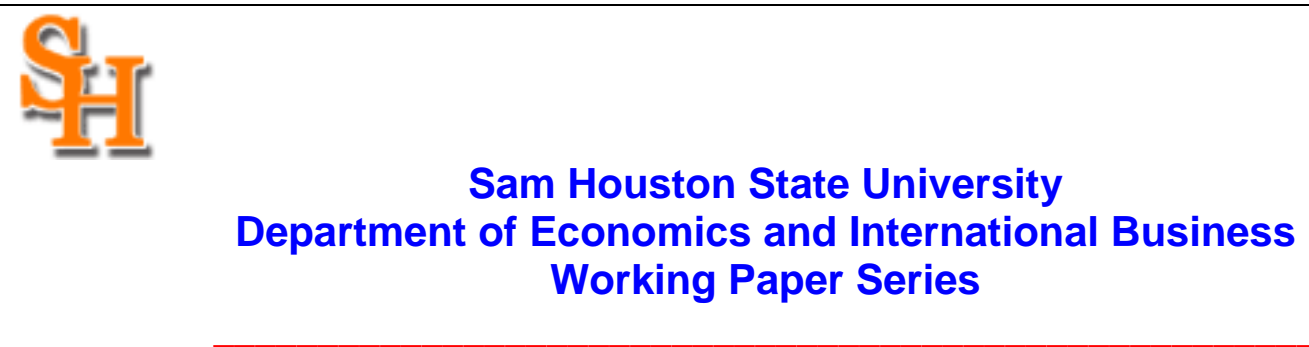

\author{
What Makes a Good Economy? An Analysis of Survey Data \\ Darren Grant
}

SHSU Economics \& Intl. Business Working Paper No. 09-09

October 2009

\begin{abstract}
:
This study analyzes nearly twenty-five years of U.S. survey data to determine the macroeconomic conditions associated with economies the public considers "good." These surveys are correlated with, but distinct from, other frequently-studied, expectations-oriented indices of consumer sentiment. The primary findings are as follows: 1) inflation and unemployment, the variables in the Phillips curve, explain much of the variation in the survey data; 2) consumers' implied loss function is nearly linear in these two variables; 3 ) the public is willing to trade off four percentage points of (increased) inflation for one percentage point of (decreased) unemployment.
\end{abstract}




\title{
WHAT MAKES A GOOD ECONOMY? AN ANALYSIS OF SURVEY DATA ${ }^{1}$
}

\author{
Darren Grant \\ Department of Economics and International Business \\ Sam Houston State University \\ Box 2118 \\ Huntsville, TX 77341 \\ dgrant@shsu.edu
}

Abstract: $\quad$ This study analyzes nearly twenty-five years of U.S. survey data to determine the macroeconomic conditions associated with economies the public considers "good." These surveys are correlated with, but distinct from, other frequently-studied, expectations-oriented indices of consumer sentiment. The primary findings are as follows: 1) inflation and unemployment, the variables in the Phillips curve, explain much of the variation in the survey data; 2) consumers' implied loss function is nearly linear in these two variables; 3 ) the public is willing to trade off four percentage points of (increased) inflation for one percentage point of (decreased) unemployment.

** This paper has several figures that are best viewed in color. **

${ }^{1}$ Mishuk Chowdhury, Sohna Jaye, Mohammed Khan, Tino Sonora, and Mark Tuttle provided key assistance in this project, for which I am grateful. Comments from participants at the 2008 Western Economic Association meetings are also appreciated. 


\section{Introduction.}

What macroeconomic conditions are associated with economies the public considers "good"? There is perhaps no more fundamental question in macroeconomics. Its answer would be useful in several ways. It would indicate how to best assess the state of the macroeconomy-whether, for example, to use Okun's Misery Index as a summary measure. It would clarify the preferences of the representative agent that populates many macroeconomic models, and thus help shape the loss functions assumed in those models. And it would cast light on the relevance of other macroeconomic theories in which the polity's preferences play a key role, such as those of political business cycles, which are feasible only if citizen satisfaction with the economy can be meaningfully manipulated over short time frames.

Three reputable surveys spanning several business cycles have regularly asked respondents to assess the state of the national economy. In this paper we use these surveys, which have not been previously analyzed, to answer the question posed above. These surveys are distinct from two others relied upon regularly by macroeconomists: the University of Michigan's Consumer Sentiment Index and the Conference Board's Consumer Confidence Index. Most of this research is future-oriented, relating consumer expectations to economic growth, while the present study focuses on assessing economic conditions in the present. Though both the Michigan and Conference Board surveys have questions inquiring about current conditions, neither asks for a general assessment of the national macroeconomy, and our analysis shows that the two sets of questions are distinct statistically.

The paper proceeds as follows. The next section introduces the three surveys, shows how they relate to each other, and describes how they differ from the Michigan and Conference Board 
indices. Section 3 then shows how various macroeconomic variables influence consumers' assessments of the state of the economy. Policy and modeling implications are then addressed in Section 4, and Section 5 concludes.

\section{Assessing the Macroeconomy.}

The Data. Of the three surveys we analyze, the longest-running is a project of $\mathrm{ABC}$ News and occasional partners since December 1985, which asks, "Would you describe the state of the nation's economy these days as excellent, good, not so good, or poor?" This survey uses an overlapping design, reporting each week the responses of about one thousand individuals who have been interviewed over the previous four weeks. The responses to this question and two others, about personal finances and the buying climate, are combined to form the "Consumer Comfort Index." We use the responses to the "good economy" question that are reported in the last week of each month, which is basically an average of all responses obtained during that month. All empirics in this paper use the month as the unit of observation, ending in December 2008 except as noted.

The second survey, almost as old but less regular, is conducted by CBS News, generally in conjunction with the New York Times (NYT). This asks about the current state of the economy: "How would you rate the condition of the national economy these days-Very Good, Fairly Good, Fairly Bad, or Very Bad?" It also asks about the change in macroeconomic conditions: "Do you think the economy is getting better, getting worse, or staying about the same?" Some months contain no surveys; other months contain multiple surveys, whose responses are then averaged. Responses to the "good economy" question are present in 147 of the 254 months between October 1987 and 
December 2008; responses to the "better/worse" question are present in 131 of those months. (Each question was occasionally asked prior to October 1987, but too infrequently to be of use here.) There is a twenty-month gap in coverage in the "good economy" question in 1989 and 1990, and several gaps of approximately six months in the "better/worse" question. (These will be visible in Figures 1 and 2 as smooth portions of the CBS/NYT lines illustrating the fraction of positive responses to each of these survey questions.) Each poll contains at least one thousand respondents.

A third poll, conducted by the Gallup organization and sponsored by USA Today, also asks two questions: one about the current state of the economy, phrased like the $\mathrm{ABC}$ News question but with slightly different response options, and one about the rate of change in the economy, phrased like the $\mathrm{CBS} / \mathrm{NYT}$ question but also with different response options. Responses to each question are reported in 111 and 109 of the 155 months between February 1997 and October 2008, respectively; there are again roughly one thousand respondents in each of these months. This survey appears to have been discontinued in October 2008 in favor of the USA Today/IHS Global Insight Economic Outlook Index, which debuted several months later and is not analyzed here.

Table 1 summarizes the questions and response options in each of these three polls. These are the only American surveys that explicitly ask for assessments of the national economy and that span at least a decade.

The first two responses to each survey's "good economy" question are considered "positive" responses. Figure 1 presents the time series of each survey's positive responses, while Figure 2 presents the time series of "better" responses to the "better/worse" questions. The level of positive responses differs across surveys, consistent with the different phrasing of the questions and answer choices. But the temporal variation in responses is quite similar, having a strong cyclical component 
punctuated with higher frequency modulations. Because of the large samples in each monthly survey, virtually none of this variation (about $0.1 \%$ ) is attributable to sampling error, whose standard deviation never exceeds 1.5 percentage points in any individual survey month. Thus even the high frequency variation is similar across surveys.

The Michigan and Conference Board surveys also present indices of current conditions (as opposed to expectations), and these too are represented in Table 1 and Figure 1. The questions asked by these surveys are distinctly different than those listed above. None asks explicitly about the overall macroeconomy, but about "business conditions", "available jobs", and durable goods purchases; three of the four questions are about the respondent himself or his local area, instead of the country as a whole. While the answers to these questions unquestionably have a substantial cyclical component, the questions themselves do not have the face validity necessary to represent an general assessment of the national macroeconomy.

Levels and Differences. Do the "good economy" questions and the "better/worse" questions measure the same construct, one in levels, the other in differences? Over what time frame do respondents measure, or perceive, changes in the strength of the macroeconomy? To find out, we regressed the percentage of "better" responses to the CBS/NYT and USA Today/Gallup "better/worse" questions on leads and lags of the percentage of positive responses "good economy" question asked by ABC News-the only one that is reported each and every month. We used two month intervals in order to condense the reporting of results, which are contained in Table 2.

In the more general, first and third regressions, positive coefficients near the current date offset negative coefficients for the recent past, suggesting a differencing interpretation, which is 
reinforced by support for the null that the coefficient sum is zero. The coefficients indicate that the "better/worse" questions are essentially backward-looking, with hindsight that extends about six months. To pin down the timing more precisely, we then conducted regressions using every feasible two-month combination of the ABC News "good economy" measure, to determine which pairs best explain the responses to the two "better/worse" questions. The second and fourth columns of the table show the optimal pairs, a backward difference of six months for the shorter USA Today series and eight months for the longer CBS /NYT series. In both cases, the $\mathrm{R}^{2}$ statistic indicates there is a minimal loss of explanatory power compared to the full set of leads and lags.

These findings indicate a reasonable degree of concordance between the level and difference assessments of the macroeconomy. However, there is an important dimension of the "better/worse" measures that is not captured in the "good economy" question. The $\mathrm{R}^{2}$ values, ranging from 0.53 to 0.73, are not that close to one. Accordingly, the analysis below will attempt to discern the macroeconomic determinants of each measure.

Latent Variables. It is valuable to have a time series that completely and succinctly summarizes the complete results of each survey question for the full time period over which it is asked. This can be done by combining two statistical techniques, an ordered probit model and transformation regression. The former views the responses to any survey question as governed by an underlying latent variable and a set of thresholds that distinguish an "excellent" response from a "good" response, and so on. Random (standard normal) variation in individual circumstances (or perceived thresholds) yields the cross-section variation in responses at any given point in time.

The latter technique expresses time as a series of splines, which can then be treated as 
independent variables in the ordered probit model. Applying the estimated coefficients to the splines yields a smoothed version of the latent variable that underlies the response percentages in each survey. This is estimated for the full time span of the survey, "filling in" any survey-less months. The extent of smoothing is governed by the number of splines; we use a large number (fifty-two over the full twenty-three year period) to smooth only gently, preserving all but the highest-frequency variation.

Figure 3 presents the results for all five questions, vertically scaled so that all latent variables have the same mean for the periods in which they overlap. (We do not present confidence intervals, as they are so small.) For both the "good economy" and "better/worse" questions the latent variables are as similar as the cutoffs, driven by the differences in response options, are different. Correlations between the "good economy" latent variables are each 0.99 ; the correlation between the "better/worse" latent variables is 0.96 .

For the "good economy" question the thresholds that convert values of the latent variable into predicted discrete responses are 1-1.5 units apart, so a corresponding increase in the latent variable implies each respondent improves her assessment of the macroeconomy by one notch. The same is true for the CBS/NYT "better/worse" measure, but not for the corresponding USA Today/Gallup measure, which only gives two response options (though respondents sometimes choose a third-see Table 1). Ironically, the percentage of "better" responses to this latter question are actually a better cardinal measure of sentiment-more closely correlated to the latent variable-because the centrallylocated threshold between the answer choices tends to be "closer to the margin." 
Dimensionality. These latent variables are, in effect, indices themselves, and can be statistically compared to the Michigan and Conference Board indices, in order to distill out their similarities and differences. A principal component analysis is a simple way to do this. Table 3 presents the results of a complete analysis of all nine variables, along with a correlation matrix. To integrate the "good economy" and "better/worse" series and address potential stationarity concerns, eight month differences are taken of all variables except the two "better/worse" series, consistent with the findings in the previous subsection. Analogous analyses, in levels and using subsets of series that overlap for longer periods of time, yield similar results.

The nine series included in this analysis can be placed into four groups: "good economy" series, Michigan and Conference Board current conditions indices, expectations indices, and "better/worse" series. This grouping is strongly supported by both the correlation matrix, in which intra-group correlations greatly exceed most inter-group correlations, and the principal components analysis, in which the within-group factor loadings are almost always similar.

In fact, except for the current conditions indices, within-group correlations are approximately 0.9. Cross-group correlations range from about 0.5 to about 0.7 , suggesting that there are four distinct dimensions represented by these four groups. This conclusion is reinforced by the principal component analysis.

This analysis yields a set of independent components that explain the overall variation of all nine series. Because so little of these series' variance is attributable to sampling error, most components could be considered statistically significant, but economic significance is restricted to the first four, which together explain $95 \%$ of the variance. These components' factor loadings, in Table 3, are easily interpretable. The first, dominant component is a simple almost-unweighted 
average of the seven series, and reflects basic business cycle variation. The second component distinguishes measures of expectations from everything else. The distinctive nature of the Michigan Current Economic Conditions Index is apparent here; in this component it is (slightly) more closely aligned with the expectations series than the "good economy" series. This reflects the predictive orientation of this index, which is based on the change in respondents' personal financial situations and the environment for durable goods purchases. The third component distinguishes the "better/worse" series, while the fourth component represents a difference between the "good economy" series and the Michigan/Conference Board current conditions indices.

The cyclical component explains $72 \%$ of the joint variance of these series. Of the remaining $28 \%$, about $3 / 7$ is contributed by the distinctiveness of the expectations indices, and another $3 / 7$ by the distinctiveness of the two survey questions analyzed here, with the remainder essentially noise. In summary, responses to the "good economy" questions asked in the ABC News, CBS/NYT, and USA Today/Gallup surveys are, despite some differences in wording and response options, very strongly related, yet distinct from expectations measures and from the current conditions indices published by the University of Michigan and the Conference Board. Responses to the "better/worse" questions are related, but not identical, to temporal differences of the good economy series. We now uncover these series' macroeconomic determinants, using the latent variables as dependent variables in the regression analyses in the next section. Because of the close correlation of each set of the latent variables we focus on the longest series of each type: ABC News, for the "good economy" question, and CBS/NYT for the "better/worse" question. Both exceed twenty years in length. 


\section{Macroeconomic Factors Affecting Assessments of the National Economy.}

To determine the factors that influence assessments of the macroeconomy, we regress the latent variables created above on the following "basic" variables: a time trend, one-year inflation, the unemployment rate, one-year output growth, a medium-term interest rate (the seven-year Treasury bill), and an index of the strength of the dollar, along with, in some specifications, the federal funds rate and detrended, logged stock prices. ${ }^{2}$ These last two variables are almost certainly endogenous, and are probably best thought of here as leading indicators, reflecting the macroeconomic optimism/pessimism of the Federal Reserve and of investors. Plots of each variable are found in Figure 4; means and standard deviations are listed in Table 4.

The form of the regression should be determined by the stationarity of the dependent and independent variables. ADF tests cannot reject the hypothesis of nonstationarity for any of them, even unemployment, but these tests probably lack power as these time series are relatively short. Fortunately, the results are very similar whether the "good economy" regression is conducted in levels or differences. Accordingly, we present both for the "good economy" question, along with a regression relating the $\mathrm{CBS} / \mathrm{NYT}$ "better/worse" latent variable to eight-month differences of the

${ }^{2}$ Data sources are as follows. Twelve-month inflation is calculated using the all-urban Consumer Price Index, from the Bureau of Labor Statistics. The unemployment rate, which is seasonally adjusted, comes from the same source. Real chain-weighted seasonally-adjusted Gross Domestic Product comes from the Bureau of Economic Analysis; each quarterly observation is assumed to pertain to the middle month of each quarter, and the other months are calculated by linear interpolation. Constant maturity seven-year Treasury bill rates and the trade-weighted index of exchange rates of the U.S.'s most important trading partners come from the Federal Reserve Bank of St. Louis. The index, originally scaled to 100, has been divided by ten here so that its variation is comparable to that of the other variables. The average monthly actual federal funds rate comes from the Federal Reserve Bank of New York. Monthly average stock prices come from Yahoo! Finance. 
independent variables, consistent with the findings in Table 2. (This difference is taken between the contemporaneous value of the variable and its eight month lag, to assure exogeneity of the basic macroeconomic variables at least.) Surprisingly, this regression is also similar to the other two, so that all findings can be discussed collectively.

The results are presented in Table 4. While the coefficients themselves have no natural interpretation (this will be offered below), they do take the expected signs and are generally significant. Furthermore, each independent variable (except for stock prices) has a standard deviation of approximately one, so the relative coefficient magnitudes are meaningful. These suggest that the unemployment rate has the largest effect on assessments of the macroeconomy. Output growth, exchange rates, and inflation have more modest effects, and interest rates the smallest effects of all.

As to explanatory power, the "good economy" and "better/worse" regressions differ greatly. The $\mathrm{R}^{2}$ values indicate that the basic macroeconomic factors explain most of the variation in the "good economy" measure, whether in levels or differences, but only just over one-third of the variation in the "better/worse" measure. The unexplained variation in the two measures is related: adding the difference of the levels latent variable to the "better/worse" variation increases the $\mathrm{R}^{2}$ value to 0.62 . Because the sampling error in these latent variables is very small and the coefficient estimates in the "good economy" differences regression and the "better/worse" regression are so similar, we can characterize the two latent variables as follows. The "good economy" measure is comprised of a dominant factor driven by standard macroeconomic measures, appended to which is a smaller, independent "animal spirits" component. The "better/worse" measure is composed, in almost equal measure, of (differences in) the macro-measures component, animal spirits, and a third factor independent of the other two. 
Note that adding the leading indicators to any regression, in contrast, increases explanatory power only slightly. Thus the three factors identified above are independent of these leading indicators, a conclusion consistent with findings of our principal component analysis and with the backwards-looking nature of the "better/worse" question. (But otherwise, in additional work not reported here, we have been unable to adequately characterize, or interpret, these last two factors.)

Figure 5 provides a visual depiction of how each factor affects the "good economy" latent variable over the full sample period-a continuous, temporal decomposition of the contributions of each factor to the value of the dependent variable. Using the coefficients estimated in Table 4 and the values of each variable at each point in time, the predicted contribution of each term (and the residual) to the value of the dependent variable is calculated, using the following identity:

$$
\begin{gathered}
Y_{t}-\bar{Y} \equiv \sum_{i} \beta_{i}\left(X_{i, t}-\bar{X}\right)+e_{t} \\
\equiv\left[\sum_{i} \max \left(\beta_{i}\left(X_{i, t}-\bar{X}_{i}, 0\right)\right)+\max \left(e_{t}, 0\right)\right]+\left[\sum_{i} \min \left(0, \beta_{i}\left(X_{i, t}-\bar{X}_{i}\right)\right)+\min \left(0, e_{t}\right)\right]
\end{gathered}
$$

where standard regression variable notation is utilized. The first line of this equation breaks the dependent variable up into components; the second line bifurcates these components into those that contribute positively, and negatively, to the current deviation of the dependent variable from its mean. The figure depicts the individual and cumulative effect of each of these components at each point in time: the actual value of the latent variable in each month equals its mean plus the cumulative positive contribution that extends upward from the horizontal axis minus the associated negative contribution that extends downward from that axis. The decompositions are presented only for the "basic model" that excludes the federal funds rate and stock values. (To interpret magnitudes, recall from Figure 3 that a one-unit change in the latent variable roughly equates to each respondent changing her opinion of the state of the economy by one notch.) 
Both the levels and differences decompositions yield similar interpretations. Measures of the real economy-unemployment and GDP growth-are most important. The latter temporally precedes the former, as is clearly visible in the figure, but is secondary in importance. Assessments of the macroeconomy are overwhelmingly driven by the strength of the labor market. Measures of the value of the dollar-inflation and exchange rates-also matter, but not greatly. Interest rates matter little (this is also true when the federal funds rate is included), as does the time trend.

Temporal variation in the error term, in both levels and differences, is strongly autocorrelated, suggesting persistent influences in assessing the macroeconomy that are unrelated to the other factors. But their interpretation is otherwise unclear-visual inspection indicates that there is no consistent relation of these errors with federal deficits, the trade deficit, oil prices, or political factors. Fortunately, for the "good economy" measure the contribution of error is small. Adding the twelvemonth lag of the dependent variable to the levels regressions, as a crude autocorrelation correction, left estimates of the long run effects of the macroeconomic measures essentially unchanged. Furthermore, estimates of the coefficient on this variable were small-at most -0.2 -suggesting that assessments of the macroeconomy are not adjusted adaptively (for the most part), but instantaneously.

Figure 6 presents the analogous decomposition for the CBS/NYT "better/worse" latent variable. The relative importance of each macroeconomic variable remains as it was previously, but, as noted previously, the overall importance of regression error is much greater, as the "better/worse" question better captures the economic intangibles involved with shifting consumer sentiment. As noted previously, differences in the "good economy" latent variable can explain only about half of this remaining variation. 


\section{Policy and Modeling Implications.}

The policy and modeling implications of our findings are best sketched out by focusing on the role of two of the most politically, empirically, and theoretically important variables in our regressions, unemployment and inflation.

Our most important finding in this regard is that the coefficients on unemployment generally exceed those on inflation by a factor of four or five, suggesting consumers are far more concerned about the former (in contrast to Lovell and Tien, 2000, analyzing the Michigan Index of Consumer Sentiment). The old "Misery Index," which simply sums the inflation and unemployment rates, is in modern times a poor indicator of public satisfaction with the economy. On average, a one percentage point decrease in unemployment increases the number of positive assessments of the economy by about fifteen percentage points, while a one percentage point decrease in inflation increases the number of positive assessments of the economy by about four percentage points.

Another way to express these relative valuations is as a tradeoff: a four percentage point increase in inflation is balanced by a one percentage point decrease in unemployment. This tradeoff need not be linear, and will not be if there are diminishing marginal rates of substitution between the two variables (technically, between lower inflation and lower unemployment). This can be explored by re-estimating our key regressions with a quadratic in inflation and unemployment and an interaction of the two, and using the results to map out "indifference curves" representing combinations of inflation and unemployment that are viewed as equally desirable by consumers, in terms of their assessments of the macroeconomy.

This has been done in Figure 7 for the ABC "good economy" latent variable, with the 
regression conducted in differences. The results for the other regressions are similar. All these regressions confirm the strong weight on unemployment, and find the quadratic/interaction terms to be (generally) statistically significant. As a result, the implied indifference curves have the concavity suggested by theory (given that both unemployment and inflation are "bads"). But the curvature is small: the indifference curves are essentially linear and the implied tradeoff between inflation and unemployment, or marginal rate of substitution, essentially constant.

This near-constant tradeoff, strongly favoring higher employment, does not accord with the assumptions of many macroeconomic models. For example, it conflicts with a Woodford-style (2003, Chapter 6) loss function that is quadratic in inflation and output, especially if equal weights are applied to each term (Rudebusch and Svensson, 1999). It also rules out a (sizeable) quadratic in interest rates (Woodford, 2003) in this loss function.

We also attempted regressions, not reported here, that "scaled" unemployment, inflation, or both, for expectations. Expected inflation was taken from the well-known Livingston survey; this variable performs slightly worse than simple inflation does, with weaker coefficient estimates and slightly smaller explanatory power. This is, it turns out, because inflationary expectations are virtually constant throughout the sample period, and so subtracting expectations from actual inflation apparently only adds noise. We also adjusted unemployment by calculating its deviation from the Natural Rate ofUnemployment, taken from Gordon's macroeconomics text (2006), and by replacing unemployment with growth in personal income, taken from the National Income and Product Accounts, also to no effect. The crude linear model used in Table 4 appears to be a fairly complete, accurate depiction of consumers' assessments of the strength of the economy.

To put these results in policy context, we assemble a simple, graphical New Keynesian 
theoretical model that integrates consumer preferences over states of the economy with the actions (or policy rules) of a central bank that has its own preferences and is subject to constraints on the economic states that can be achieved through monetary policy. This can be done in a natural way because New Keynesian models can express each of these relations using in terms of unemployment and inflation.

In sketching out this model, we as sume the "good economy" assessments represent consumer preferences over states of the economy. While our evidence is suggestive on this point, it is not definitive. But there is considerable complementary evidence, from European surveys, that happiness is influenced by the same macroeconomic factors that stand out here: unemployment, especially, and inflation (Roos, 2006; DiTella, MacCulloch, and Oswald, 2001; Oswald, 1997), with long-term interest rates and economic growth being secondary (Welsch, 2007; Oswald, 1997). Lux (2008) lays out the microfoundations by which macroeconomic fundamentals generate dynamic responses to opinion surveys.

The model, graphically depicted in Figure 8, has four elements. First, feasible states of the economy are characterized by a simple Phillips Curve that outlines the tradeoffs between unemployment and inflation that are possible in the near term, the different combinations of which can be "produced" by the central banker. The marginal rate of substitution, of unemployment for inflation, is greater in economies with more slack, giving the curve the standard isoquant shape.

The second element is a Taylor Rule, which describes the central bank's policy response to the current state of the economy. If the economy has excess slack, the central bank will lower interest rates, lower unemployment, and raise inflation; if the economy is too tight, it will do the opposite. In both cases the central bank attempts to steer the economy toward its preferred point on the Phillips 
Curve, point B in Figure 8. Taylor Rules are typically linear, as in the figure, and expressed in terms of inflation and economic growth, which can be linked to unemployment via Okun's Law. The upward-sloping T*, T1, T2 lines in Figure 8 represent combinations of unemployment and inflation that generate the same policy response: contractionary in $\mathrm{T} 1$, and expansionary in $\mathrm{T} 2$.

Point $\mathrm{B}$, on line $\mathrm{T}^{*}$, can be viewed as the intersection of the "isoquant" of feasible economic states with the "indifference curve" representing the central bank's preferences over states of the economy. Since unemployment and inflation are both "bads," this indifference curve is concave rather than convex, and values closer to the origin are preferred. This is the third element of the model.

The last element is the one estimated here: consumer preferences over states of the economy, as in Figure 7. Instead of assuming that the central bank automatically adopts the welfare function of the representative agent, these curves allow that agent to speak for herself. Based on these preferences, consumers also have a preferred point on the Phillips Curve, but it may not coincide with that of the central bank. In Figure 8 consumers prefer point A, an economy with less unemployment and higher inflation, to point B. This could occur, for example, if consumers are more myopic than the central bank, and did not comprehend the long run effects of inflationary expectations.

The data exist to estimate three of these curves (the first, second, and fourth); and under basic assumptions about market interest rates and the target inflation and unemployment (or output growth) rates, of the type made by Taylor originally, line $\mathrm{T}^{*}$ can be identified as well. From this points A and B could be ascertained and directly compared. This exercise, worthwhile in theory, is difficult to execute in practice, because the data must accurately resolve not just the slope but also the curvature of curves $\mathrm{CC}$ and $\mathrm{NN}$ in Figure 8. Nevertheless, even first-order slope estimates indicate that points A and B are unlikely to overlap. 
Adopting Boivin and Giannoni's (2006, Figures 1 and 2) recent estimates for the U.S., a monetary policy shock lowering output by $1.5 \%$ was required to reduce inflation by $0.5 \%$ over the period 1959-1979, an Okun's Law-adjusted Phillips Curve relation with a slope of about -1. During the more recent, 1979-2002 period, however, this relation changed to a slope of -0.5 : a two percentage point increase in unemployment is required to lower inflation by one percentage point. This slope differs greatly from that of consumers' indifference curves, which is about -4 . This implies there is a sizeable dissonance between the macroeconomic conditions the public desires and those that are attainable, and suggests that point A would indeed lie far northwest of point B. The small slope of the Taylor Rule (about 1/3 when expressed in terms of inflation and unemployment, again using Okun's Law) only reinforces this point.

This dissonance has two ramifications. First, it indicates that time consistency is a legitimate concern of the central bank: that the sequence of myopically optimal economic states is less preferred than the sequence chosen by a farsighted central banker. Second, it suggests that there is room for political actors, in the legislative and executive branches, to adjust short run economic states to advance their political support in the short run-the classic political business cycle. Section 3 indicates that if this is done, however, it must be by sacrificing long term inflation for short term employment growth-the error terms in the decompositions in Figures 5 and 6 show little evidence of a biennial, or quadrennial, fall "bump" that would correspond to federal elections. 


\section{Conclusion.}

What makes a good economy? A strong labor market, predominantly, though the public also values lower inflation, more economic growth, and a stronger dollar. Changes in these basic measures also help explain the whether the public views the economy as getting better or getting worse. But both measures, especially the latter, also respond to "animal spirits" that have no obvious, measurable economic correlate.

Across three key surveys, the phrasing of the "good economy" question and response options differs, engendering differences in raw response probabilities; however, these responses are governed by the same underlying latent variable. This latent variable is distinct from the expectations-focused indices published by the University of Michigan and (to a smaller extent) the Conference Board, though all of these surveys exhibit cyclicality. The same is true for the "better/worse" question, which looks backward, not forward, with hindsight of six to eight months.

The very strong weight given to unemployment in these surveys, and the nearly linear tradeoff between unemployment and inflation estimated in our regressions, pose a formidable challenge to those representative-agent macroeconomic models that weight price stability more heavily, and that utilize or imply a loss function that is quadratic in inflation and unemployment (or economic growth). But it is no longer necessary to prescribe a particular objective function for these representative agents based only on theory-in these surveys, she can speak for herself. 
Table 1. "Good Economy" indices and their construction.

\begin{tabular}{|c|c|c|}
\hline $\begin{array}{l}\text { Survey Title } \\
\text { and Sponsor }\end{array}$ & Question(s) Asked of Respondents & $\begin{array}{l}\text { Temporal Span, Survey Frequency, and Response } \\
\text { Reporting (Phone Survey unless Noted) }{ }^{\mathrm{E}}\end{array}$ \\
\hline $\begin{array}{l}\text { ABC News } \\
\text { "Consumer } \\
\text { Comfort Index" A }\end{array}$ & $\begin{array}{l}\text { "Would you describe the state of the nation's economy } \\
\text { these days as excellent, good, not so good, or poor?" }\end{array}$ & $\begin{array}{l}\text { Dec. 1985-present, weekly, nationwide. Percentages } \\
\text { in each category are reported for about } 1,000 \\
\text { respondents over the previous four weeks. The } \\
\text { values reported in the last survey of month are used. }\end{array}$ \\
\hline $\begin{array}{l}\text { New York Times / } \\
\text { CBS News Poll: } \\
\text { Levels }{ }^{\text {B }}\end{array}$ & $\begin{array}{l}\text { "How would you rate the condition of the national } \\
\text { economy these days? Is it very good, fairly good, } \\
\text { fairly bad, or very bad?" }\end{array}$ & $\begin{array}{l}\text { Oct. } 1987 \text {-present, at irregular intervals, nationwide. } \\
\text { Percentages in each category are reported for least } \\
1,000 \text { respondents over the previous three or five } \\
\text { days. All surveys in each month are averaged. }\end{array}$ \\
\hline $\begin{array}{l}\text { New York Times / } \\
\text { CBS News Poll: } \\
\text { Changes }{ }^{\text {B }}\end{array}$ & $\begin{array}{l}\text { "Do you think the economy is getting better, getting } \\
\text { worse, or staying about the same?" }\end{array}$ & $\begin{array}{l}\text { Sept. 1976-present, irregular intervals, nationwide. } \\
\text { Percentages in each category are reported for at } \\
\text { least } 1,000 \text { respondents over the previous three to } \\
\text { five days. All surveys in each month are averaged. }\end{array}$ \\
\hline $\begin{array}{l}\text { USA Today / } \\
\text { Gallup Poll: } \\
\text { Levels }\end{array}$ & $\begin{array}{l}\text { "How would you rate economic conditions in this } \\
\text { country today-as excellent, good, only fair, or poor?" }\end{array}$ & $\begin{array}{l}\text { Jan. } 1997-O c t .2008 \text {, at irregular intervals, } \\
\text { nationwide. Percentages in each category are } \\
\text { reported for at least } 1,000 \text { respondents over the } \\
\text { previous three to five days. All surveys in each } \\
\text { month are averaged. }\end{array}$ \\
\hline $\begin{array}{l}\text { USA Today / } \\
\text { Gallup Poll: } \\
\text { Changes }{ }^{\mathrm{C}}\end{array}$ & $\begin{array}{l}\text { "Right now, do you think that economic conditions in } \\
\text { the country as a whole are getting better or getting } \\
\text { worse?" (the percent volunteering the response "same" } \\
\text { is also reported) }\end{array}$ & $\begin{array}{l}\text { Feb. } 1997-\text { Oct. } 2008 \text {, at irregular intervals, } \\
\text { nationwide. Percentages in each category are } \\
\text { reported for at least } 1,000 \text { respondents over the } \\
\text { previous three to five days. All surveys in each } \\
\text { month are averaged. }\end{array}$ \\
\hline
\end{tabular}




\begin{tabular}{|l|l|l|}
\hline $\begin{array}{l}\text { University of } \\
\text { Michigan Index of } \\
\text { Current Economic } \\
\text { Conditions D }\end{array}$ & $\begin{array}{l}\text { "Would you say that you are better off or worse off } \\
\text { financially than you were a year ago?" and "Generally } \\
\text { speaking, do you think now is a good or bad time for } \\
\text { people to buy major household items?" }\end{array}$ & $\begin{array}{l}\text { Monthly, Jan. 1978-present; three or four times } \\
\text { yearly, 1951-Dec. 1977, continental U.S. At least } \\
500 \text { respondents over the course of the month. } \\
\text { Percentage responses (with one decimal place) to } \\
\text { each question are available online. The fraction of } \\
\text { positive minus negative responses for each question } \\
\text { is calculated, averaged, and indexed to 1966:1. }\end{array}$ \\
\hline $\begin{array}{l}\text { Conference Board } \\
\text { Indesent Situation }\end{array}$ & $\begin{array}{l}\text { C } \\
\text { "How would you rate present general business } \\
\text { "What would you say about available jobs in your area } \\
\text { right now-plentiful, not so many, or hard to get?" }\end{array}$ & $\begin{array}{l}\text { Monthly, June 1977-present; bi-monthly, Feb. } \\
\text { 1967-Apr. 1977, nationwide. Throughout the } \\
\text { month about 3,500 respond to a mailing of 5,000 } \\
\text { surveys, made at the end of the previous month. } \\
\text { The fraction of all non-neutral responses that are } \\
\text { positive is calculated and indexed to 1985. }\end{array}$ \\
\hline
\end{tabular}

Notes:

${ }^{\text {A }}$ Available from 2004 forward from: http://abcnews.go.com/PollingUnit/CCI/, with earlier values obtained via request to the Washington Post in 2005, when they were a partner with ABC News for the Consumer Comfort Survey.

${ }^{B}$ Available from: http://www.cbsnews.com/stories/2007/10/12/politics/main3362530.shtml

${ }^{\text {C }}$ Data used only from 1997 forward, available from: http://www.pollingreport.com/consumer.htm

${ }^{D}$ Breakdowns of response percentages by demographic group available from: http://www.sca.isr.umich.edu/subset/

${ }^{E}$ The full time span of each survey is not always used; the months covered are listed in Section 2. While all surveys are ongoing, this analysis ends with the survey of December 2008. 
Table 2. Regressions of "Better / Worse" Measures on Leads/Lags of "Good Economy" Positive Responses (coefficient estimates, with standard errors in parentheses).

PERCENT SAYING THE ECONOMY IS “GETTING BETTER”

\begin{tabular}{|c|c|c|c|c|}
\hline $\begin{array}{l}\text { Percent Saying the } \\
\text { Economy Is "Excellent" } \\
\text { or "Good" in ABC Survey }\end{array}$ & $\mathrm{CBS} / \mathrm{NYT}$ & $\mathrm{CBS} / \mathrm{NYT}$ & $\begin{array}{l}\text { USA Today / } \\
\text { Gallup }\end{array}$ & $\begin{array}{l}\text { USA Today / } \\
\text { Gallup }\end{array}$ \\
\hline Six Month Lead & $\begin{array}{l}-0.01 \\
(0.09)\end{array}$ & & $\begin{array}{l}-0.09 \\
(0.14)\end{array}$ & \\
\hline Four Month Lead & $\begin{array}{c}0.19 \\
(0.16)\end{array}$ & & $\begin{array}{c}0.11 \\
(0.19)\end{array}$ & \\
\hline Two Month Lead & $\begin{array}{c}0.17 \\
(0.15)\end{array}$ & & $\begin{array}{c}0.29 \\
(0.18)\end{array}$ & \\
\hline One Month Lead & & $\begin{array}{c}0.58 \\
(0.05)\end{array}$ & & $\begin{array}{c}0.86 \\
(0.09)\end{array}$ \\
\hline Current Month & $\begin{array}{c}0.37 \\
(0.15)\end{array}$ & & $\begin{array}{c}0.77 \\
(0.19)\end{array}$ & \\
\hline Two Month Lag & $\begin{array}{l}-0.02 \\
(0.14)\end{array}$ & & $\begin{array}{l}-0.08 \\
(0.19)\end{array}$ & \\
\hline Four Month Lag & $\begin{array}{l}-0.44 \\
(0.15)\end{array}$ & & $\begin{array}{l}-0.55 \\
(0.19)\end{array}$ & \\
\hline Five Month Lag & & & & $\begin{array}{l}-0.76 \\
(0.08)\end{array}$ \\
\hline Six Month Lag & $\begin{array}{l}-0.12 \\
(0.15)\end{array}$ & & $\begin{array}{l}-0.15 \\
(0.19)\end{array}$ & \\
\hline Seven Month Lag & & $\begin{array}{l}-0.50 \\
(0.05)\end{array}$ & & \\
\hline Eight Month Lag & $\begin{array}{l}-0.12 \\
(0.14)\end{array}$ & & $\begin{array}{l}-0.20 \\
(0.18)\end{array}$ & \\
\hline Ten Month Lag & $\begin{array}{l}-0.03 \\
(0.15)\end{array}$ & & $\begin{array}{l}-0.23 \\
(0.18)\end{array}$ & \\
\hline Twelve Month Lag & $\begin{array}{c}0.06 \\
(0.11)\end{array}$ & & $\begin{array}{c}0.22 \\
(0.13)\end{array}$ & \\
\hline $\begin{array}{l}\text { F-Statistic on Null that } \\
\text { Coefficient Sum Is } 0 \\
\text { (p value) }\end{array}$ & $\begin{array}{c}0.81 \\
(0.37)\end{array}$ & $\begin{array}{c}6.06 \\
(0.02)\end{array}$ & $\begin{array}{l}1.68 \\
(0.20)\end{array}$ & $\begin{array}{l}2.25 \\
(0.14)\end{array}$ \\
\hline $\mathrm{R}^{2}$ & 0.55 & 0.53 & 0.73 & 0.70 \\
\hline
\end{tabular}

Note: Time trend also included. $\mathrm{N}=124$ for $\mathrm{CBS} / \mathrm{NYT}$ survey and $\mathrm{N}=108$ for USA Today/Gallup. 
Table 3. Exploring Dimensionality using Principal Components.

\begin{tabular}{|c|c|c|c|c|c|c|c|c|c|c|c|c|}
\hline \multirow[b]{2}{*}{ Variable } & \multicolumn{6}{|c|}{ CORRELATIONS ( $\mathrm{N}$ in parentheses) } & \multicolumn{2}{|c|}{$\begin{array}{c}\text { "Better/Worse" } \\
\text { Latent Variables }\end{array}$} & \multicolumn{4}{|c|}{$\begin{array}{c}\text { PRINCIPAL COMPONENT } \\
\text { FACTOR LOADINGS } \\
(\mathrm{N}=127) \\
\end{array}$} \\
\hline & $\begin{array}{l}\text { NYT / } \\
\text { CBS }\end{array}$ & $\begin{array}{l}\text { USA / } \\
\text { Gallup }\end{array}$ & Michigan & $\begin{array}{l}\text { Conf. } \\
\text { Board }\end{array}$ & Michigan & $\begin{array}{l}\text { Conf. } \\
\text { Board }\end{array}$ & $\begin{array}{l}\text { NYT / } \\
\text { CBS }\end{array}$ & $\begin{array}{l}\text { USA / } \\
\text { Gallup }\end{array}$ & $1^{\text {st }}$ P.C. & $2^{\text {nd }}$ P.C & $3^{\text {rd }}$ P.C. & $4^{\text {th }}$ P.C. \\
\hline $\begin{array}{l}\text { ABC News } \\
\text { Good Econ. }\end{array}$ & $\begin{array}{l}0.96 \\
(205)\end{array}$ & $\begin{array}{l}0.95 \\
(127)\end{array}$ & $\begin{array}{l}0.73 \\
(266)\end{array}$ & $\begin{array}{c}0.79 \\
(128)\end{array}$ & $\begin{array}{r}0.65 \\
(266)\end{array}$ & $\begin{array}{c}0.57 \\
(128)\end{array}$ & $\begin{array}{l}0.77 \\
(252)\end{array}$ & $\begin{array}{l}0.70 \\
(130)\end{array}$ & 0.37 & -0.24 & 0.15 & -0.25 \\
\hline $\begin{array}{l}\text { NYT / CBS } \\
\text { Good Econ. }\end{array}$ & & $\begin{array}{l}0.95 \\
(127)\end{array}$ & $\begin{array}{l}0.72 \\
(205)\end{array}$ & $\begin{array}{l}0.71 \\
(128)\end{array}$ & $\begin{array}{l}0.64 \\
(205)\end{array}$ & $\begin{array}{c}0.59 \\
(128)\end{array}$ & $\begin{array}{l}0.79 \\
(205)\end{array}$ & $\begin{array}{l}0.70 \\
(130)\end{array}$ & 0.37 & -0.19 & 0.09 & -0.42 \\
\hline $\begin{array}{l}\text { USA/Gallup } \\
\text { Good Econ. }\end{array}$ & & & $\begin{array}{l}0.75 \\
(127)\end{array}$ & $\begin{array}{c}0.71 \\
(127)\end{array}$ & $\begin{array}{l}0.61 \\
(127)\end{array}$ & $\begin{array}{l}0.60 \\
(127)\end{array}$ & $\begin{array}{c}0.78 \\
(127)\end{array}$ & $\begin{array}{l}0.68 \\
(127)\end{array}$ & 0.37 & -0.18 & 0.10 & -0.43 \\
\hline $\begin{array}{l}\text { Michigan } \\
\text { Current }\end{array}$ & & & & $\begin{array}{c}0.69 \\
(131)\end{array}$ & $\begin{array}{l}0.70 \\
(269)\end{array}$ & $\begin{array}{l}0.68 \\
(131)\end{array}$ & $\begin{array}{l}0.60 \\
(252)\end{array}$ & $\begin{array}{c}0.59 \\
(130)\end{array}$ & 0.34 & 0.16 & 0.18 & 0.40 \\
\hline $\begin{array}{l}\text { Conf. Board } \\
\text { Current }\end{array}$ & & & & & $\begin{array}{c}0.43 \\
(131)\end{array}$ & $\begin{array}{l}0.43 \\
(131)\end{array}$ & $\begin{array}{l}0.55 \\
(128)\end{array}$ & $\begin{array}{c}0.44 \\
(128)\end{array}$ & 0.29 & -0.31 & 0.50 & 0.56 \\
\hline $\begin{array}{l}\text { Michigan } \\
\text { Expectations }\end{array}$ & & & & & & $\begin{array}{c}0.86 \\
(131)\end{array}$ & $\begin{array}{l}0.53 \\
(252)\end{array}$ & $\begin{array}{l}0.53 \\
(130)\end{array}$ & 0.30 & 0.60 & 0.06 & -0.13 \\
\hline $\begin{array}{l}\text { Conf. Board } \\
\text { Expectations }\end{array}$ & & & & & & & $\begin{array}{c}0.57 \\
(128)\end{array}$ & $\begin{array}{c}0.52 \\
(128)\end{array}$ & 0.30 & 0.59 & 0.05 & 0.04 \\
\hline $\begin{array}{l}\text { NYT / CBS } \\
\text { Better/Worse }\end{array}$ & & & & & & & & $\begin{array}{r}0.96 \\
(130)\end{array}$ & 0.35 & -0.15 & -0.49 & 0.18 \\
\hline $\begin{array}{l}\text { USA/Gallup } \\
\text { Better/Worse }\end{array}$ & & & & & & & & & 0.31 & -0.10 & -0.64 & 0.22 \\
\hline $\begin{array}{l}\text { Joint Variance } \\
\text { Explained }\end{array}$ & & & & & & & & & $72 \%$ & $11 \%$ & $8 \%$ & $4 \%$ \\
\hline
\end{tabular}

Note: All variables are scaled to have the same variance for the principal component analysis, as is standard. Consistent with the findings in Table 2 , eight month differences are used for all "good economy" latent variables, Michigan indices, and Conference Board indices. 
Table 4. Regression Results (coefficient estimates, with standard errors in parentheses).

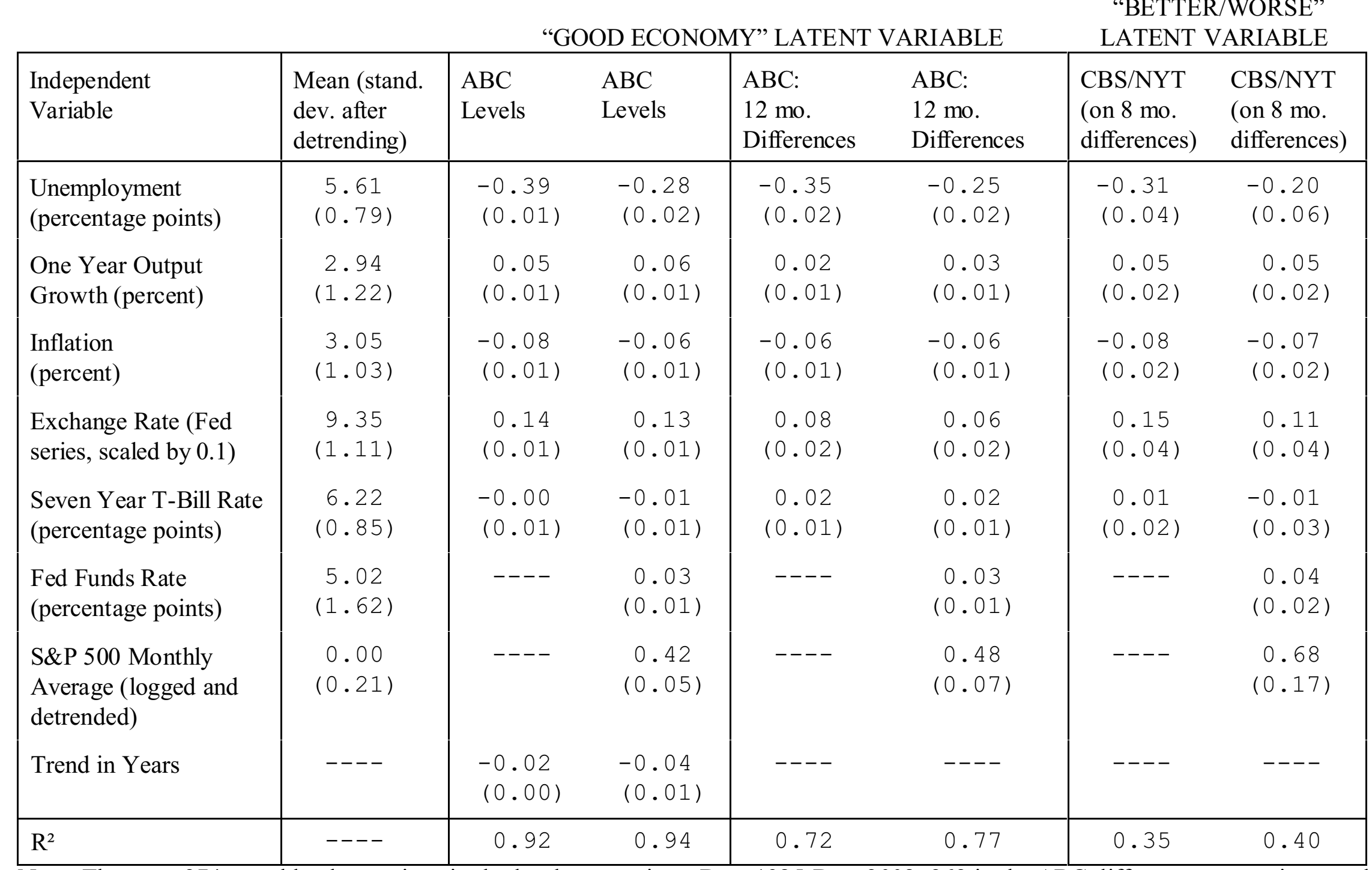

Note: There are 274 monthly observations in the levels regressions, Dec. 1985-Dec. 2008; 262 in the ABC differences regressions, and 252 in the CBS/NYT regressions. Each regression also includes a constant. 


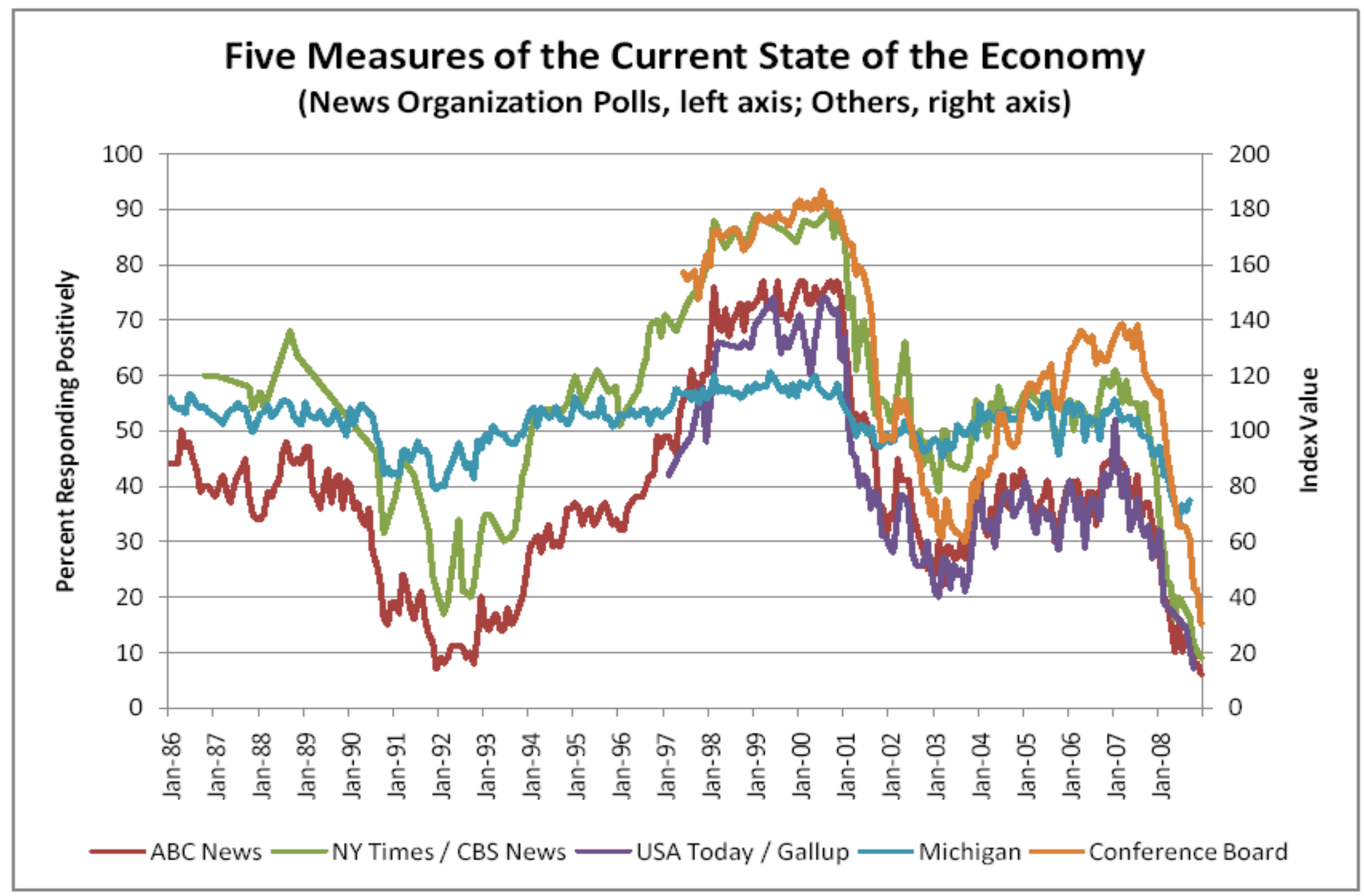




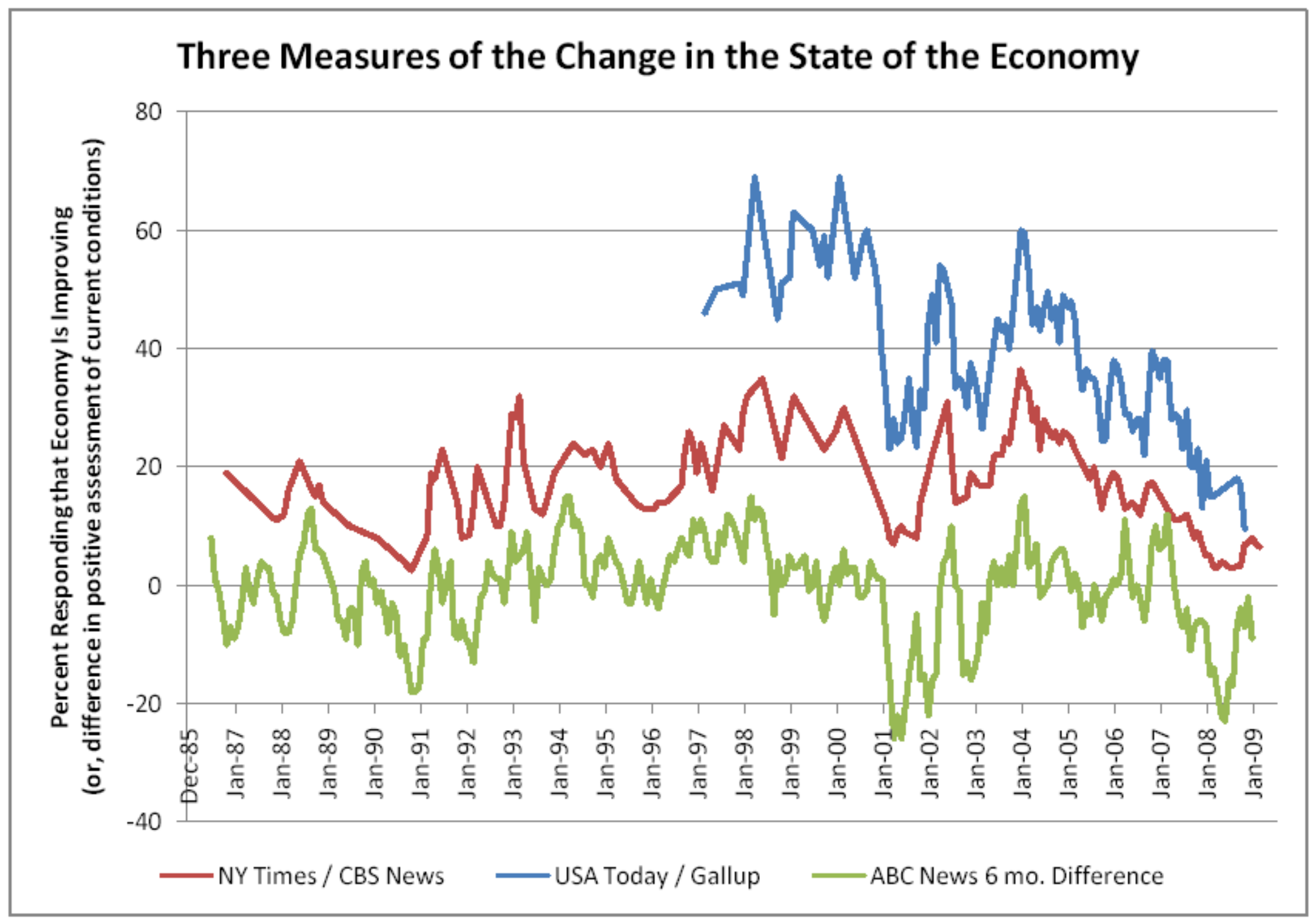


Figure 3. Latent Variables for Levels and Change Measures.
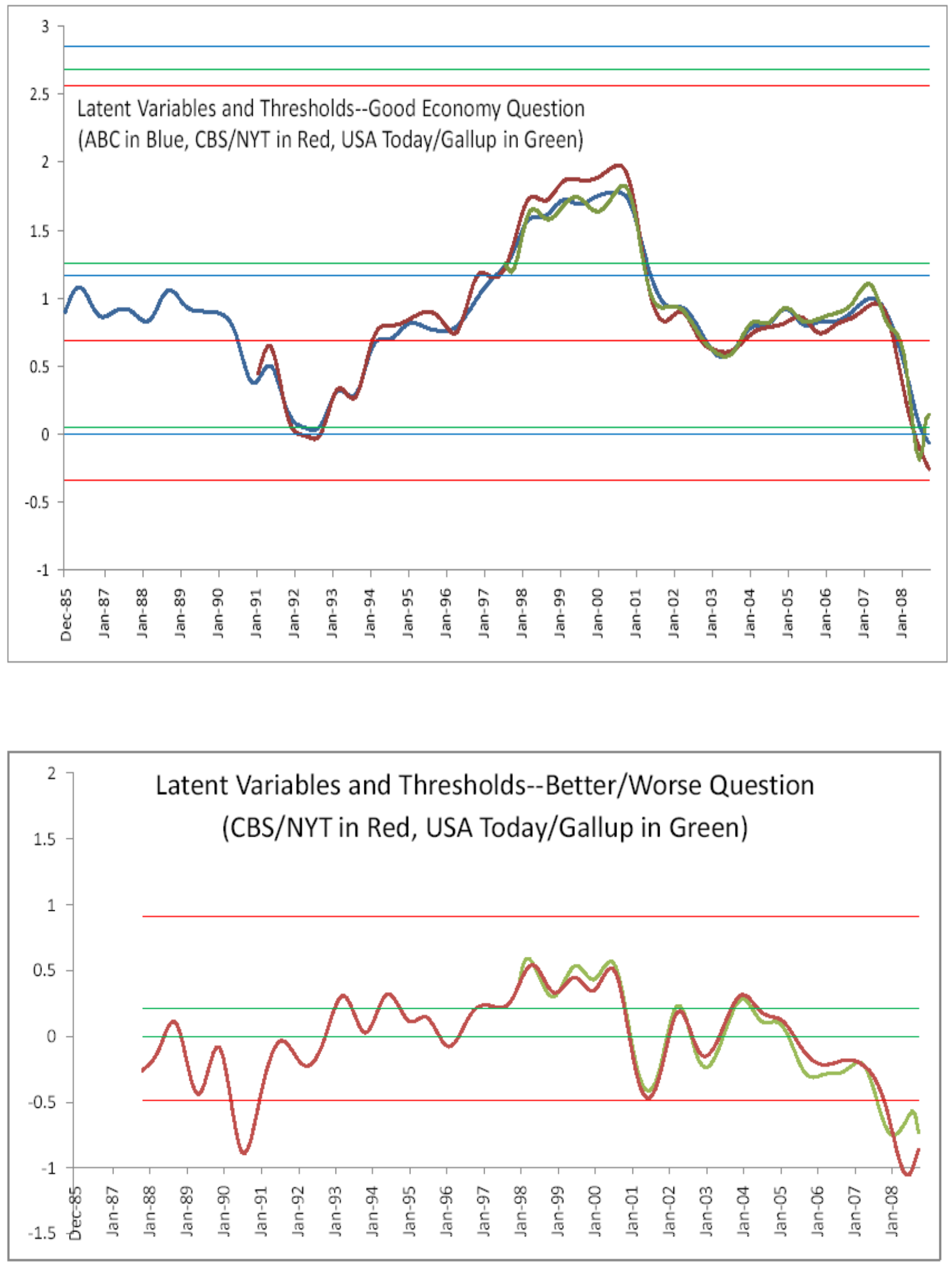
Figure 4. Macro Data.
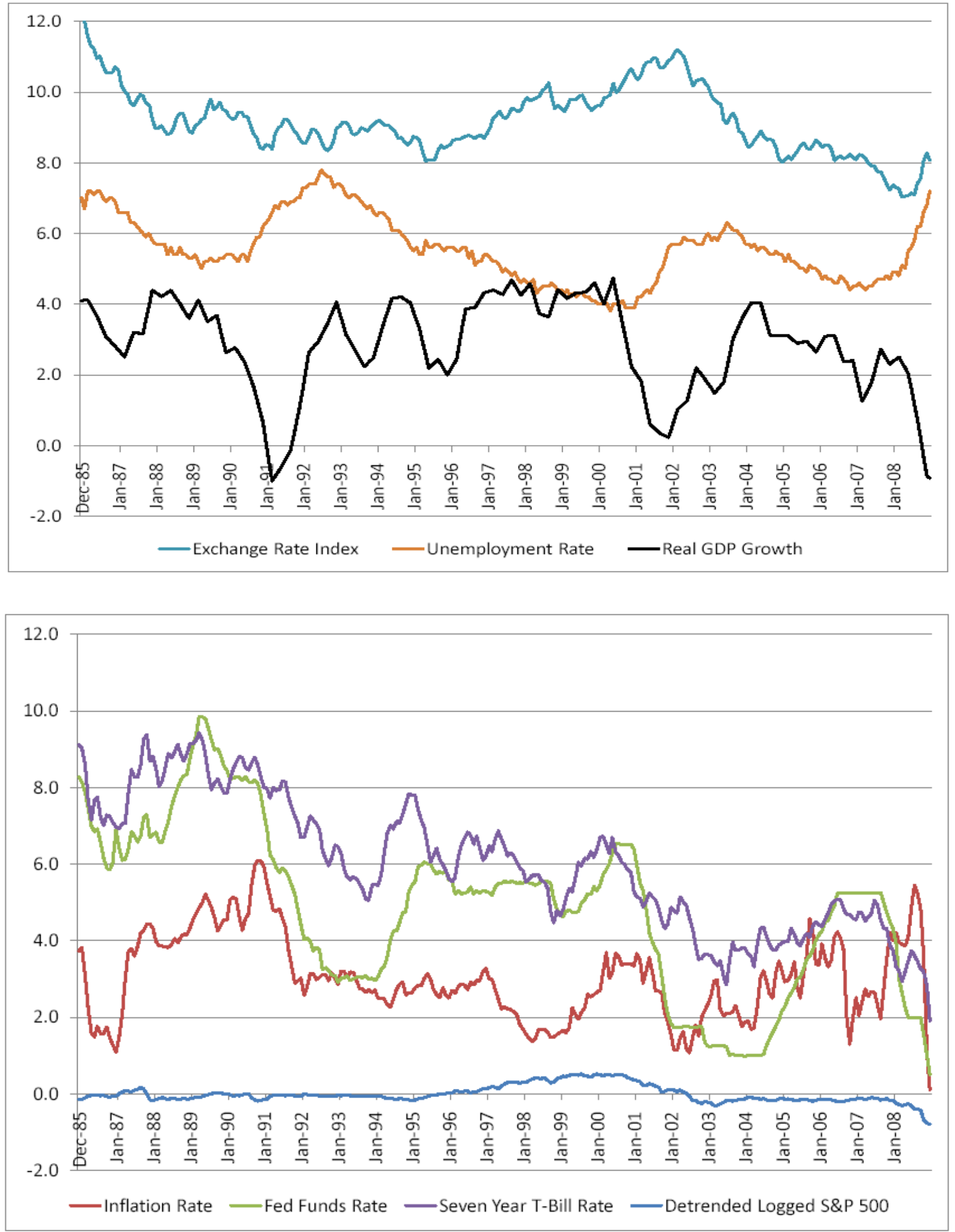
Figure 5. Decomposition of ABC News Latent Variable. Top: Levels. Bottom: Differences.
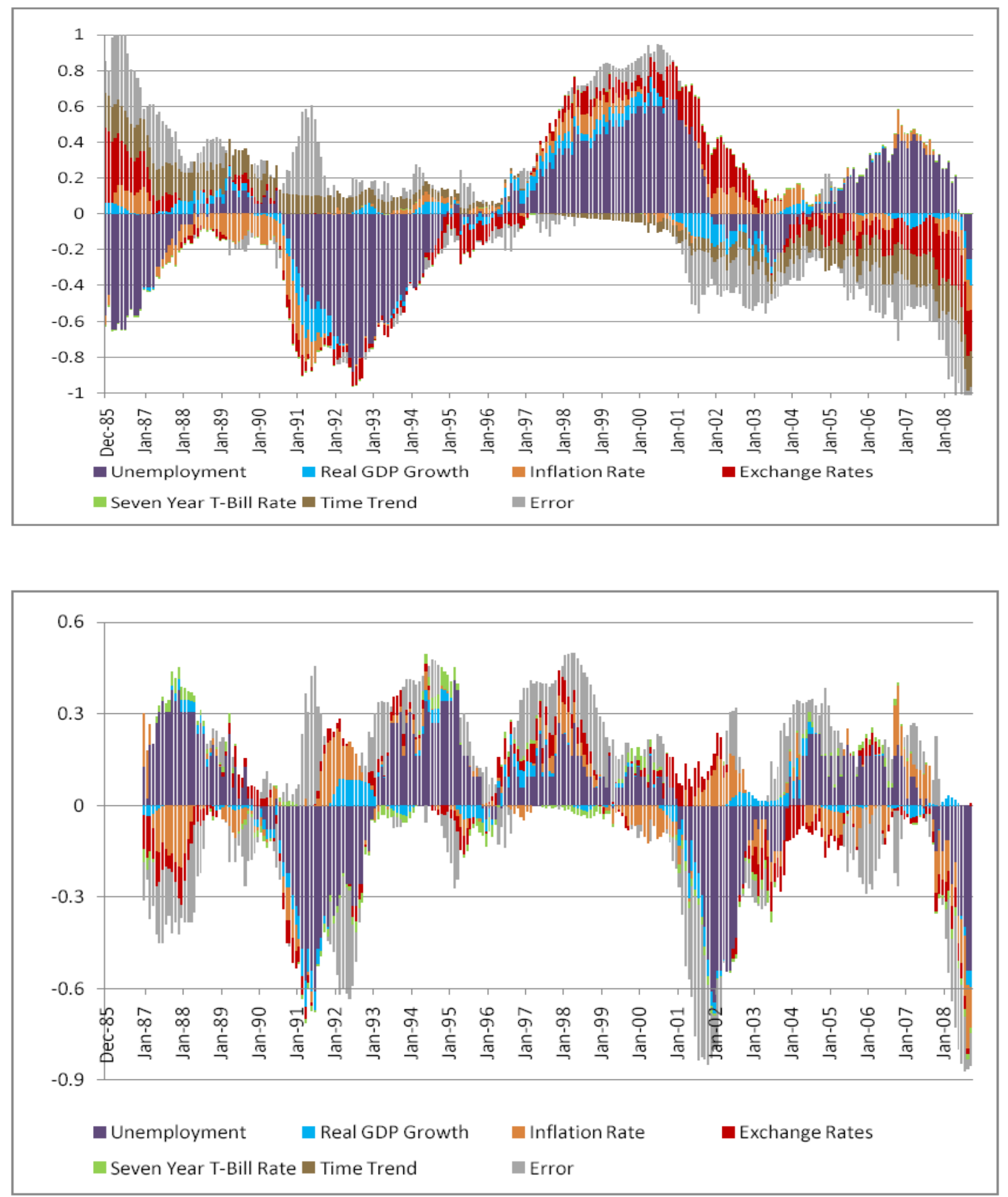
Figure 6. Decomposition of NY Times Change Latent Variable.

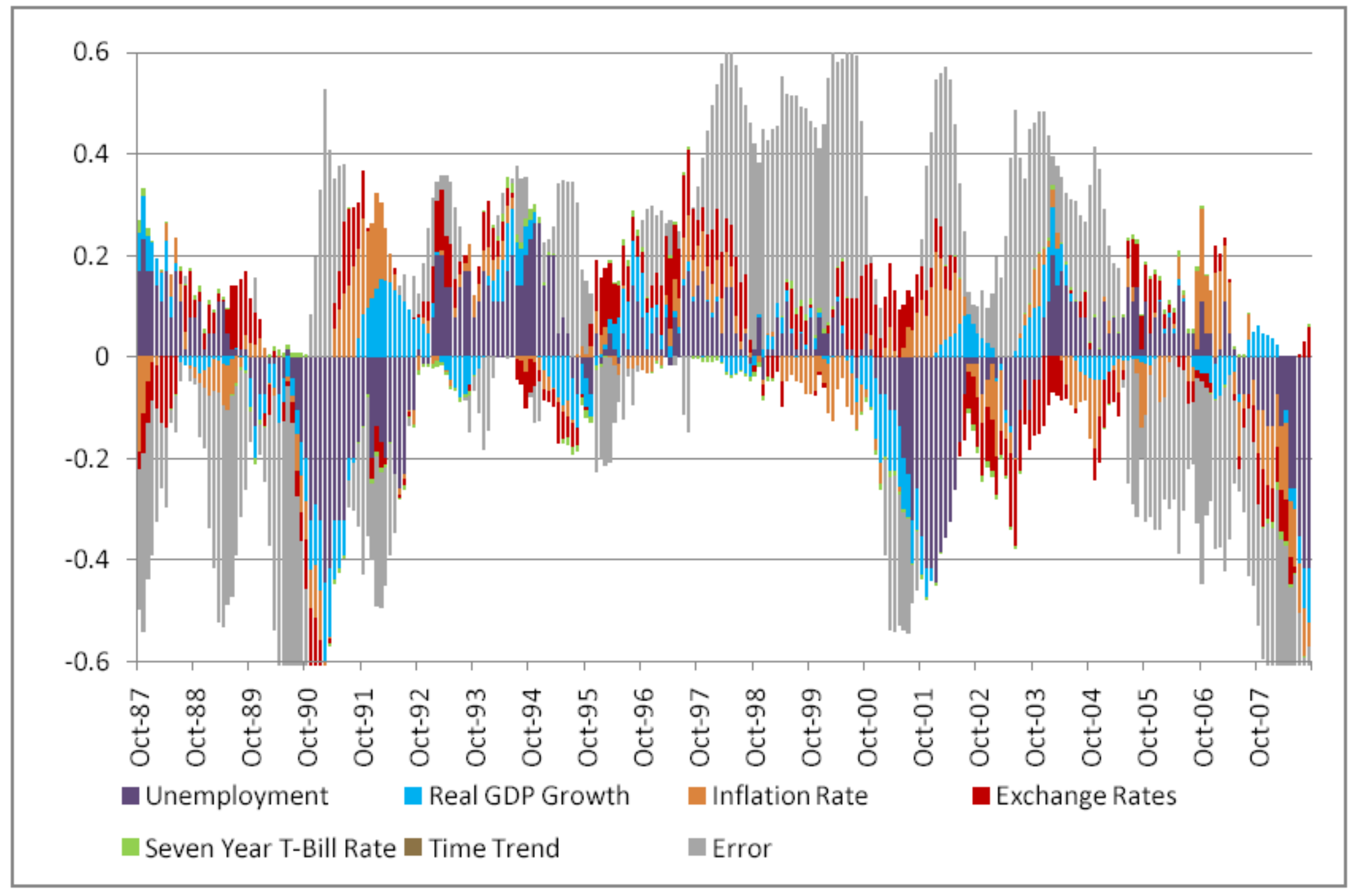


Figure 7. Implied Indifference Curves.

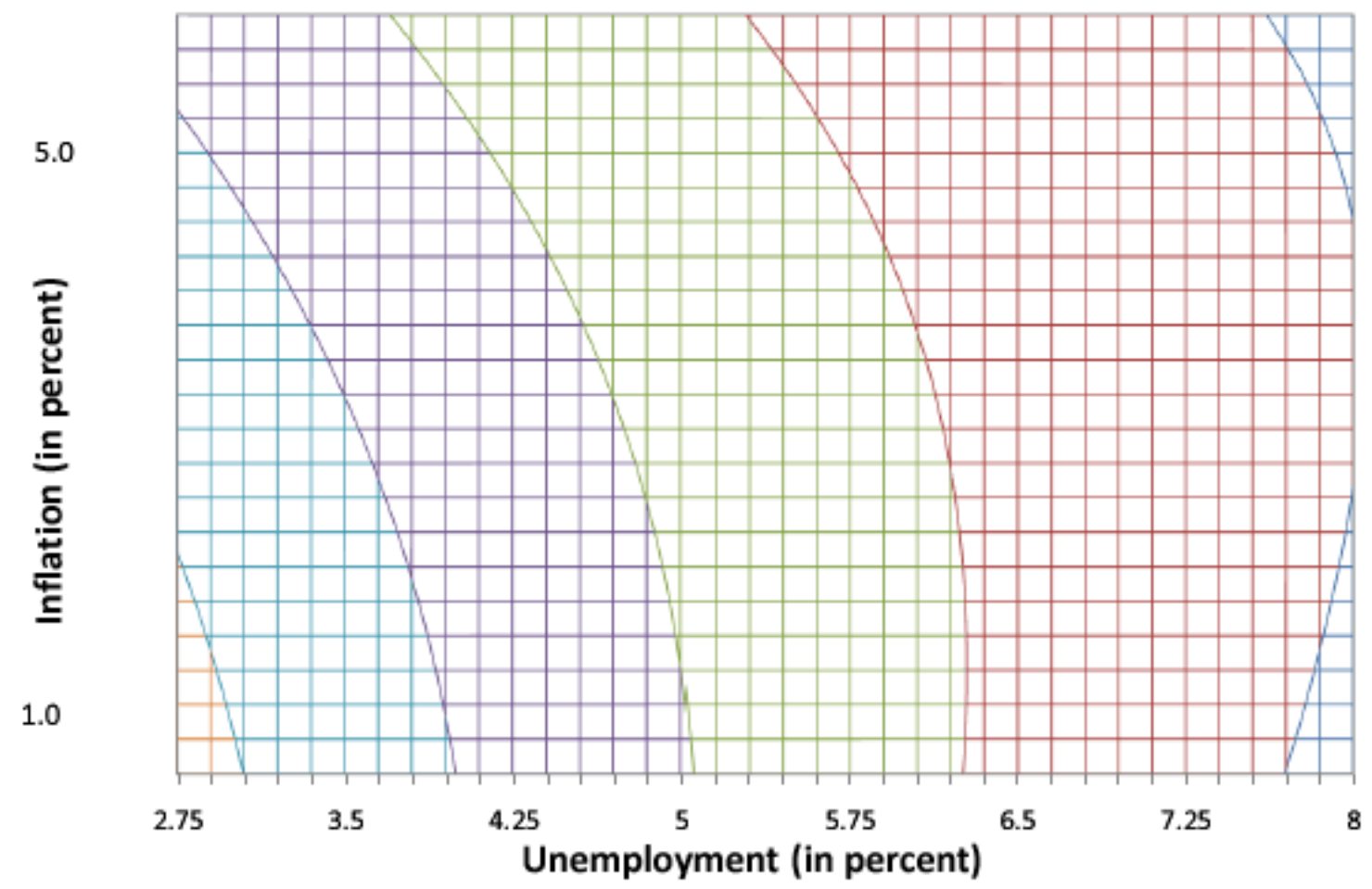

Note: These are calculated using the $\mathrm{ABC}$ News latent variable difference regressions that include quadratics, and an interaction, of unemployment and inflation, and hold all other variables constant. Indifference curves map 0.5 unit differentials in values of the latent variable. 
Figure 8. Theoretical Relation between Fed's Taylor Rule, Consumer Preferences over the State of the Economy, and Policy Tradeoffs Embodied in the Phillips Curve.

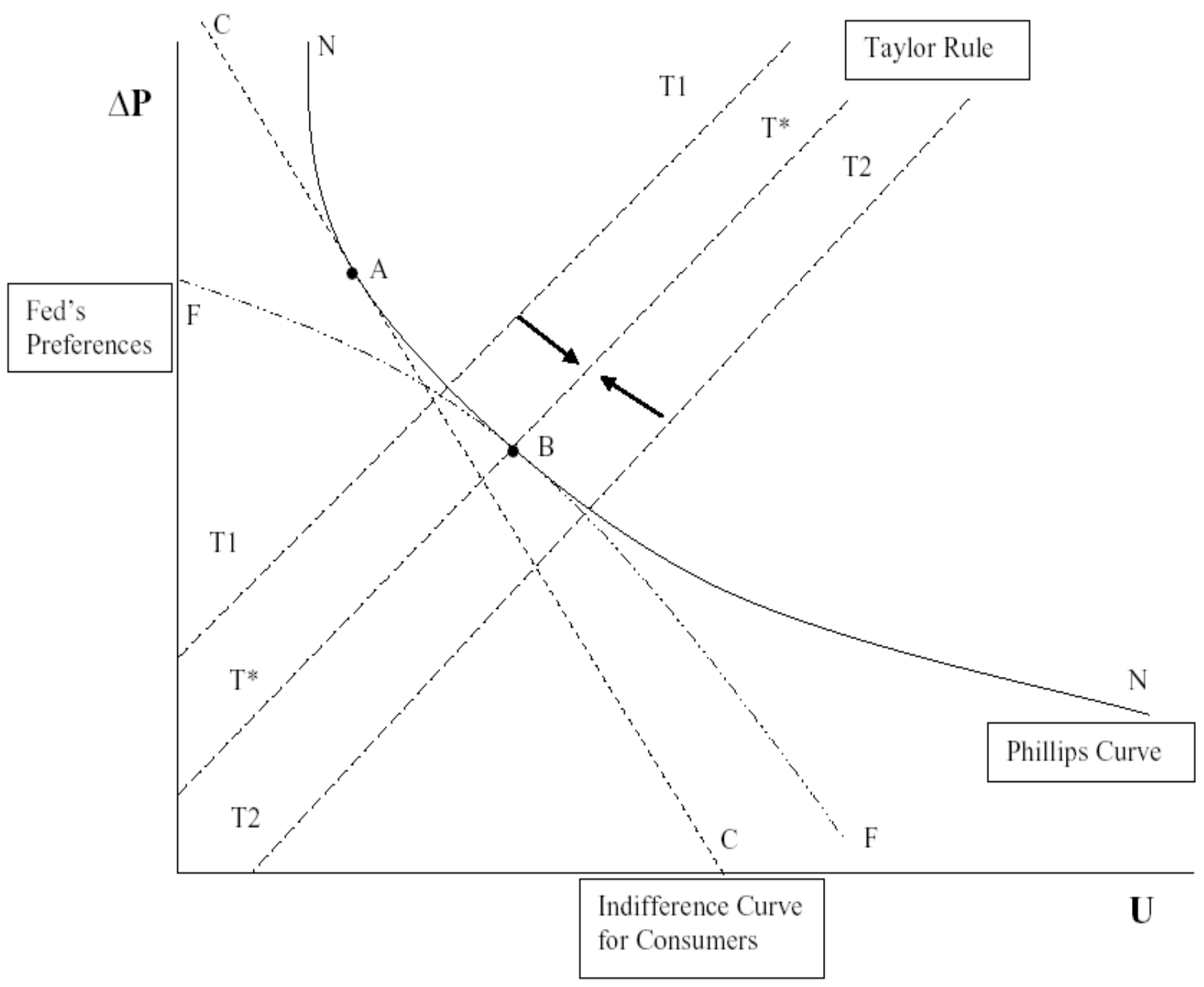




\section{REFERENCES}

Boivin, Jean, and Marc Giannoni. 'Has Monetary Policy Become More Effective?" Review of Economics and Statistics 88,3:445-462 (2006).

DiTella, Rafael, Robert MacCulloch, and Andrew Oswald. "Preferences over Inflation and Unemployment: Evidence from Surveys of Happiness," American Economic Review 91:335$341(2001)$.

Gordon, Robert. Macroeconomics, $10^{\text {th }}$ edition. Upper Saddle River, New Jersey: Pearson (2006).

Lovell, Michael C., and Pao-Lin Tien. "Economic Discomfort and Consumer Sentiment," Eastern Economic Journal 26,1:1-8 (2000).

Ludvigson, Sydney. "Consumer Confidence and Consumer Spending," Journal of Economic Perspectives 18, 2:29-50 (2004).

Lux, Thomas. "Rational Forecasts or Social Opinion Dynamics: Identification of Interactions Effects in a Business Climate Survey." Kiel Institute for the World Economy Working Paper 1424 (2008).

Oswald, Andrew. "Happiness and Economic Performance," Economic Journal 107,5:1815-1831 (1997).

Ross, Michael W.M. "The Factors behind Consumer Confidence," Manuscript, Universität Dortmund (2006).

Rudebusch, Glenn, and Lars Svensson. "Policy Rules for Inflation Targeting," in J.B. Taylor, ed., Monetary Policy Rules. Chicago: University of Chicago Press (1999).

Welsch, Heinz. "Macroeconomics and Life Satisfaction: Revisiting the 'Misery Index'," Journal of Applied Economics 10,12:237-251 (2007).

Woodford, Michael. Interest and Prices: Foundations of a Theory of Monetary Policy. Princeton: Princeton University Press (2003). 